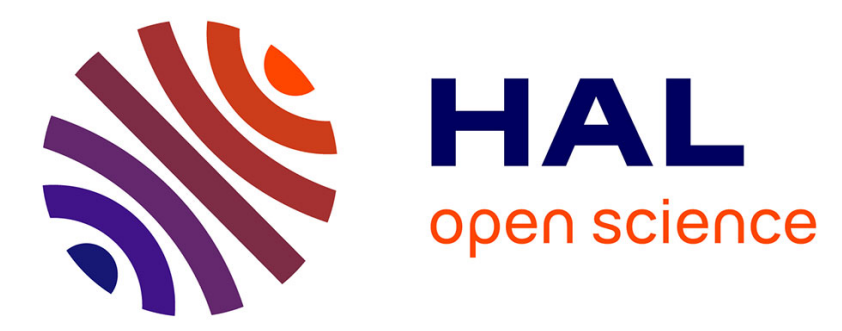

\title{
Comparison of postfire mortality in endemic Corsican black pine (Pinus nigra ssp. laricio) and its direct competitor (Pinus pinaster) \\ Pimont, Prodon, Rigolot
}

\section{- To cite this version:}

Pimont, Prodon, Rigolot. Comparison of postfire mortality in endemic Corsican black pine (Pinus nigra ssp. laricio) and its direct competitor (Pinus pinaster). Annals of Forest Science, 2011, 68 (2), pp.425-432. 10.1007/s13595-011-0031-0 . hal-00930766

\section{HAL Id: hal-00930766 https://hal.science/hal-00930766}

Submitted on 1 Jan 2011

HAL is a multi-disciplinary open access archive for the deposit and dissemination of scientific research documents, whether they are published or not. The documents may come from teaching and research institutions in France or abroad, or from public or private research centers.
L'archive ouverte pluridisciplinaire HAL, est destinée au dépôt et à la diffusion de documents scientifiques de niveau recherche, publiés ou non, émanant des établissements d'enseignement et de recherche français ou étrangers, des laboratoires publics ou privés.

$$
\text { Copyright }
$$




\title{
Comparison of postfire mortality in endemic Corsican black pine (Pinus nigra ssp. laricio) and its direct competitor (Pinus pinaster)
}

\author{
François Pimont • Roger Prodon • Eric Rigolot
}

Received: 1 January 2010 / Accepted: 21 June 2010/Published online: 3 March 2011

(C) INRA and Springer Science+Business Media B.V. 2011

\begin{abstract}
- Introduction Laricio pine (Pinus nigra J.F. Arn. ssp. laricio (Poiret) Maire var Corsicana Hyl.) is a form of black pine endemic to Corsica, that may now be under threat due to current fire regimes and competition with maritime pine (Pinus pinaster Aiton).

- Material and methods This study aimed to compare postfire mortality in laricio and maritime pine in a mixed stand in northwest Corsica. Diameter at breast height, bark char, bole length charred, and tree mortality were measured in 661 trees 9 months after a severe fire. Logistic regressions were used to determine mortality probabilities which, to compare the two species, were expressed in relation to species, age, and species-independent severity indicators.

- Results For all ages considered, laricio pine mortality was up to threefold that of maritime pine. The differences between the species were most significant in pines less than 60 years old and exposed to severe conditions. This was mainly due to differences in growth rate between the two species.

- Conclusion Considering life history traits, maritime pine appears to be better adapted than laricio pine to the risk of fire. As the frequency of major fires in Corsica is on the
\end{abstract}

Handling Editor: Reinhart Ceulemans

F. Pimont $(\bowtie) \cdot$ E. Rigolot

Mediterranean Forest Ecology Research Unit

(UR 629, Fire Physics and Ecology Team),

INRA, National Institute for Agronomic Research,

Site Agroparc, Domaine de Saint Paul,

84914 Avignon Cedex 9, France

e-mail: pimont@avignon.inra.fr

R. Prodon

Ecologie et Biogéographie des Vertébrés, UMR 5175, EPHE,

1919 route de Mende,

34293 Montpellier Cedex 5, France increase, constituting a real threat for endemic species, we provide a few management guidelines for conservation of the laricio pine.

Keywords Fire impact · Pine · Postfire mortality - Survival . Logistic regression

\section{Introduction}

Current fire regimes in the Mediterranean area may be a threat to high-elevation pines, depending on their ability to regenerate or survive after a fire (Pausas et al. 2008). In Corsica, large stands of laricio pine (Pinus nigra J.F. Arn. subsp. laricio (Poiret) Maire var Corsicana Hyl.) recently sustained severe damage during 10 forest fires in 2000 and 2003. Laricio pine often forms mixed stands with maritime pine (Pinus pinaster Aiton), its main competitor (Zaghi 2008). Both pines are shade-intolerant and thrive on poor, acid soils. Laricio and maritime pines both played a significant role in the Corsican landscape during the late Holocene. After the last ice age, laricio pine was the first to undergo extension (2500 BP), followed by maritime pine (between 2000 and 1000 BP). Charcoal fragments suggest that fire and slash-and-burn agriculture favor the expansion of maritime pine (Carcaillet et al. 1997), and its postfire regeneration is far denser than that seen with P. nigra (Pausas et al. 2008). Maritime pine currently covers $18 \%$ of Corsican forest, compared with $31 \%$ for laricio pine (French National Forestry Inventory-FNI). But the range of the laricio pine may decrease in coming years due to increasing fire frequency, and to better understand this potential recession, we undertook to investigate, and report here, the survival ability of these two species. 
The laricio subspecies of the black pine is endemic to Corsica (Afzal-Rafii and Dodd 2007) and is included in annex I to Council Directive 79/409/EEC on the Conservation of Natural Habitats. Mature and overmature laricio stands are the habitat of several endemic bird species, including the Corsican nuthatch (Sitta whiteheadi), (Prodon and Thibault 2002a, b). Because of the rarity, beauty, and ecological importance of old pines, forest managers go to great lengths to conserve damaged stands. But the presence of many dead trees increases the risk of healthy trees being attacked by bark beetles (Jenkins 1990; Ryan and Amman 1994; Sullivan et al. 2003), and foresters are also looking to mitigate the visual impact of damaged forest. Thus, the conservation of laricio pine in its competition with maritime pine requires tools that can be used to assess the likelihood of mortality in damaged trees, coupled with pertinent forest management prescriptions.

The ability of a tree to survive a fire depends on crown shape, bud size, bark thickness (related to diameter at breast height, DBH) and root structure. Crown injury is related to the intensity of the surface fire and to flame length. Stem injury is related to both fire residence time in surface fuels and bark thickness (Ryan 1982; Rego and Rigolot 1990). Logistic models of postfire mortality in pines have been developed for several species (see Fernandes et al. 2008 for a review in European pines). Model variables consist of dendrometric parameters (height, diameter at breast height) and several indicators of fire severity (crown scorch volume, bole length charred, bark char). Mortality generally occurs 2 or 3 years after the fire, but may be observed in old pines 13 years later (Rigolot 1992; McHugh and Kolb 2003; Sullivan et al. 2003).

Although some mortality data are available for P. nigra (Ordonez et al. 2005), no model has been developed for laricio pine. Also, no comparison has yet been made between laricio and maritime pines. In the study reported here, we used logistic regressions to model individual short- term mortality in relation to tree size and fire severity in the two pines. These models can help managers by predicting pine mortality but cannot be used directly for a satisfactory comparison between the two species as a given fire will not produce the same damage in the two trees. In addition, comparing trees of a given diameter makes no sense in terms of an analysis of population dynamics. In order to compare more rigorously their resistance to fire, additional variables were used, to understand how the two species will be threatened in a context of competition under increasing fire occurrence.

\section{Materials and methods}

Tree diameter, fire severity characteristics, and tree mortality were measured in Corsica in 2004 in a mixed stand of laricio and maritime pines 9 months after a major wildfire, and the results were used to compute logistic mortality models for each species.

\subsection{Study sites}

The study area consisted of a mixed stand of laricio and maritime pines in the Cinto-Rotondo forestry zone. Two sites were selected on the south-facing slope of the Tartagine valley and on the north-facing slope of the Melaja forest (Haute Corse; $42^{\circ} 29^{\prime} 00 \mathrm{~N}, 9^{\circ} 11^{\prime} 00 \mathrm{E}$ ). The wildfire occurred in late August caused by lightning during the heat wave and severe drought of 2003, and burned 1,836 ha (i.e., $52 \%$ of the Tartagine and Melaja forests). The fire was very severe (stand-replacing fire) over most of the area but patchy because of the uneven terrain with many rocky outcrops. This resulted in unburned patches from place to place, offering a wide range of severities. No major fires had been recorded in the area prior to 2003, and most of the forest could be considered as old growth.
Table 1 Tree sampling design and variables measured

\begin{tabular}{lll}
\hline & Range & Sampling classes \\
\hline DBH & & \\
Maritime pine & $5-65 \mathrm{~cm}$ & 6 classes \\
Laricio pine & $5-75 \mathrm{~cm}$ & 7 classes \\
BLC & $0-100 \%$ & $0-20 \%$ : low severity \\
& & $20-30 \%$ : medium severity \\
& & $30-60 \%$ : high severity \\
BC & & $>60 \%$ : very high severity \\
& 0: bark not blackened & No sampling class for this variable \\
& 1: slightly or not completely blackened & \\
& 2: moderate uniformly but moderately blackened & \\
& 3: deeply charred & \\
\hline
\end{tabular}

$D B H$ diameter at breast height, $B L C$ bole length charred, $B C$ bark char 


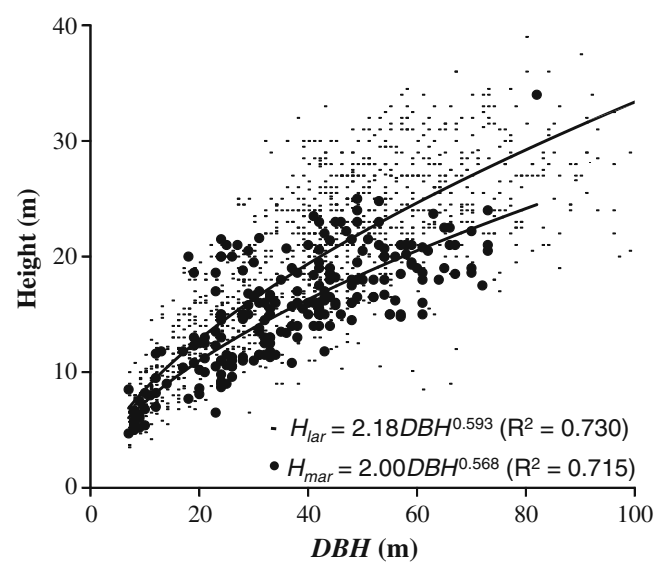

Fig. 1 Relationship between height and diameter at breast height $(D B H)$ for the two pine species (FNI data: Cinto-Rotondo area)

\subsection{Data collection}

Sampling was stratified according to both DBH and bole length charred (BLC) to avoid correlations between tree size and thermal damage in the dataset (Table 1). DBH was measured to within $1 \mathrm{~cm}$ and trees grouped into classes $10 \mathrm{~cm}$ apart. Bark thickness (BT, in $\mathrm{cm}$ ) at breast height was computed from DBH (in $\mathrm{cm}$ ), using FNI relationships valid for the Cinto-Rotondo zone $(B T=0.0667 D B H+0.0104$ for maritime pine and $B T=0.044 D B H+0.0117$ for laricio pine). Bark factor (BF) was computed according to Ryan et al. (1994): $B F=1-e^{-B T(\mathrm{~cm})}$.

BLC, i.e., the greatest percentage of bole height charred by the fire, was measured using a Suunto dendrometer. Severities were divided into four BLC classes: low, medium, high, and very high fire severities (Table 1). These BLC classes were derived from mortality probabilities obtained by a preliminary sampling of 50 trees, and corresponded to $0-25 \%, 25-50 \%, 50-75 \%$, and $75-100 \%$ dead trees. BLC was our only indicator of flame height and canopy damage (Hely et al. 2003; Sidoroff et al. 2007). Even if crown scorch volume is often the most accurate predictor (Ryan and Reinhardt 1988; McHugh and Kolb 2003), it cannot be measured a few months after a fire because scorched needles cannot be distinguished from needles yellowed by the postfire decaying of the tree, and because most have already fallen to the ground.

Bark char depth was estimated on each quadrant of the bole $0.5 \mathrm{~m}$ above ground level and ranged from zero when the bark was not blackened, to three when it was deeply blackened. Mean bark char (BC) was computed as the mean of the four bark char depth values.

Tree status $M$ (alive=0, dead=1) was also estimated, the tree being considered dead in the absence of green needles and buds ready to open (Rigolot 2004).

\subsection{Data analysis}

Logistic regressions of tree status were computed in relation to BF, BLC, and BC using "R" software (Ihaka and Gentleman 1996; Eq. 1). The regression coefficients were tested using Wald's $\chi^{2}$.

$$
P_{\text {mortality }}=\frac{1}{1+e^{-\left(\sum_{i} a_{i} \times X_{i}\right)}}
$$

where $X_{i}$ is the different variables and $a_{i}$ their coefficient.

The significance of the explanatory variables was evaluated from deviance ratio $\chi^{2}$ tests. Models were selected on the basis of the Akaike criterion (McCullagh and Nelder 1989). Data sparseness (due to the fact that the tree was either dead or alive) could have led to underestimated deviance, and thus to an overestimation of the model's joint significance (McCullagh and Nelder 1989). The original dataset was therefore resampled on the basis of the linear predictor $\sum a_{i} \times X_{i}$ obtained from the original logistic regression in eight tree classes. We compared the average mortality probabilities in these groups, and this nonsparse dataset was used to evaluate deviance and thus provide an unbiased joint significance (McCullagh and Nelder 1989). The concordance index CI (Regelbrugge and Conard 1993) was used to evaluate model efficiency and consists in systematically comparing the predicted mortality probability for each pair of trees, one dead and the other alive. When the mortality probability of the live tree was lower than for the dead tree, the pair was said to be concordant. Otherwise, the pair was said to be discordant. The CI was computed as:

$C I=\frac{N C}{T}$

where $T$ is the total number of pairs, and $N C$ is the number of concordant pairs.

Table 2 Outline of measured variables

\begin{tabular}{|c|c|c|c|c|c|}
\hline & Number of trees & DBH mean, [min-max] & BLC mean, [min-max] & $\mathrm{BC}$ mean, $[\min -\max ]$ & Mortality \\
\hline Maritime pine & 330 & $35 \mathrm{~cm},[5-65 \mathrm{~cm}]$ & $36 \%,[0-100]$ & $1.85,[0-3]$ & $30 \%$ \\
\hline Laricio pine & 331 & $40 \mathrm{~cm},[5-75 \mathrm{~cm}]$ & $41 \%,[0-100]$ & $1.96,[0-3]$ & $40 \%$ \\
\hline
\end{tabular}

$D B H$ diameter at breast height, $B L C$ bole length charred, $B C$ bark char 
Table 3 Logistic models of mortality for maritime and laricio pine

\begin{tabular}{|c|c|c|c|c|c|c|c|}
\hline & Intercept & $\mathrm{BF}$ & BLC & $\mathrm{BC}$ & Deviance & $\mathrm{DF}$ & $\mathrm{CI}$ \\
\hline Mar1 & $-0.759 \pm 0.76$ & $-9.32 \pm 1.29 * * *$ & $0.0499 \pm 0.89^{* * *}$ & $2.71 \pm 0.49 * * *$ & 224 (Null 403) AIC 232 & 326 & 0.908 \\
\hline Mar2 & $0.773 \pm 0.62$ & $-5.39 \pm 0.85 * * *$ & $0.0679 \pm 0.0080 * * *$ & & 268 (Null 403) AIC 274 & 327 & 0.864 \\
\hline Mar3 & $-0.527 \pm 0.738$ & $-9.04 \pm 1.21 * * *$ & & $3.53 \pm 0.47 * * *$ & 262 (Null 403) AIC 268 & 327 & 0.873 \\
\hline Lar1 & $0.222 \pm 0.800$ & $-9.95 \pm 1.32 * * *$ & $0.103 \pm 0.014 * * *$ & $1.20 \pm 0.47 *$ & 189 (Null 446) AIC 197 & 327 & 0.948 \\
\hline Lar2 & $1.13 \pm 0.69$ & $-8.78 \pm 1.17 * * *$ & $0.118 \pm 0.014 * * *$ & & 196 (Null 446)AIC 202 & 328 & 0.943 \\
\hline Lar3 & $-0.376 \pm 0.721$ & $-8.47 \pm 1.04 * * *$ & & $3.10 \pm 0.40^{* * *}$ & 291 (Null 446) AIC 297 & 328 & 0.857 \\
\hline
\end{tabular}

$B F$ bark factor, $B L C$ bole length charred, $B C$ bark char, $D$ deviance, $A I C$ Akaike criterion, $D F$ degrees of freedom, $C I$ concordance index Mar1, Mar2, and Mar3 are models for maritime pine, with three or two variables. Lar1, Lar2, and Lar3 are models for laricio pine, with three or two variables

$* * * P<0.001 ; * * P<0.001 ; * P<0.1$ ( $\chi^{2}$ test)

\subsection{Comparing mortality in the two pines}

A given damage level results in a species-dependent mortality probability. But damage itself is speciesdependent. Any comparison of species-specific mortality must therefore include species-specific damage differences, which in practice is difficult because fire conditions around a given tree are unknown. We chose to rely on damage indices (referred to later as independent indices) scaled identically for both species. For example, crown scorch volume cannot be considered as an independent index, because it depends on crown structure. On the other hand, $\mathrm{BLC}$ can be seen as an independent indicator of flame height for identical DBH and height. But, for a given DBH, laricio pine is slightly higher than maritime pine (Fig. 1), so BLC is not an independent index. We therefore introduced $B L C_{\bmod }(D B H)=\frac{\text { FlameHeight }}{H_{\operatorname{mar}}(D B H)}$, as an independent index of flame height:

$B L C_{\bmod }(D B H)=B L C$, for maritime pine

$B L C_{\text {mod }}(D B H)=B L C \frac{H_{\text {lar }}(D B H)}{H_{\text {mar }}(D B H)}$, for laricio pine

where $H_{l a r}$ and $H_{\text {mar }}$ are mean heights of laricio and maritime pines, respectively.

As the insulating property of bark does not vary substantially between species (van Mantgem and Schwartz 2003), BC may be assumed to be an independent index of residence time. Here, bark structure differences were

Table 4 Deviance and joint significance after resampling linear predictors (no sparseness effect)

\begin{tabular}{lllll}
\hline & Deviance & Null deviance & DF (Null DF) & Significance \\
\hline Mar1 & 8.1 & 181 & $6(7)$ & $* * *$ \\
Mar2 & 4.6 & 133 & $6(7)$ & $* * *$ \\
Lar1 & 5.92 & 257 & $6(7)$ & $* * *$ \\
\hline
\end{tabular}

$* * * P<0.001 ; * * P<0.001 ; * P<0.1$ ( $\chi^{2}$ test $)$ assumed to be negligible. We then fitted logistic models in relation to the species (maritime $=0$, laricio $=1$ ), $\mathrm{BF}, \mathrm{BC}$, and $\mathrm{BLC}_{\text {mod }}$.

DBH depends on species growth, so comparing tree mortality on the basis of diameter does not provide any valuable information with regard to population dynamics. As a life history trait, mortality should be analyzed in relation to tree age (A). Age/DBH relationships were derived from FNI data available for the forestry zone:

Maritime pine : $D B H=3.02 A^{0.588}\left(r^{2}=0.405 ; 54\right.$ pines $)$ Laricio pine $: D B H=1.93 A^{0.639}\left(r^{2}=0.564 ; 276\right.$ pines $)$

As the study sites with basal areas between 18 and $25 \mathrm{~m}^{2} / \mathrm{ha}$ and densities between 180 and $250 \mathrm{stems} /$ ha were representative of the forestry zone, these relationships were assumed to be valid at these sites.

Finally, mortality probability was modeled in relation to species, age (A), and two independent indices (flame height and residence time) to compare species resistance.

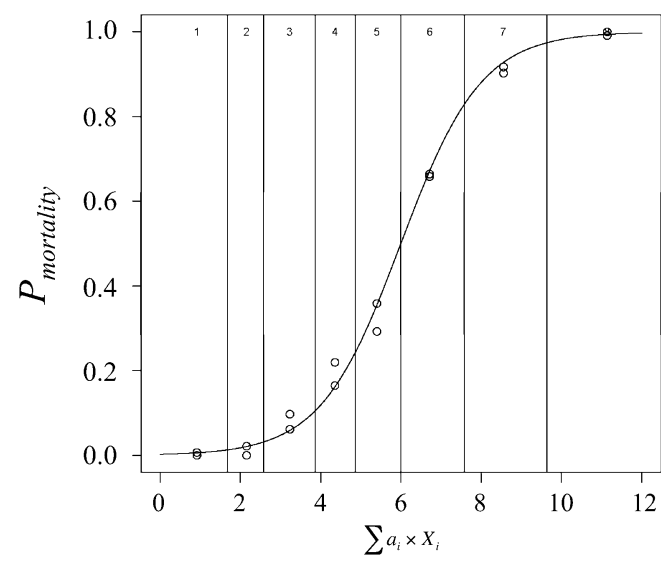

Fig. 2 Logistic regression of laricio mortality probability after resampling (i.e., without any sparseness effect) for the Larl model 
Fig. 3 Mortality probability (for a diameter at breast height of $35 \mathrm{~cm}$ in relation to bole length charred $(B L C)$ and bark char $(B C))$ in maritime (left) and laricio (right) pines (Marl and Lar1 models)
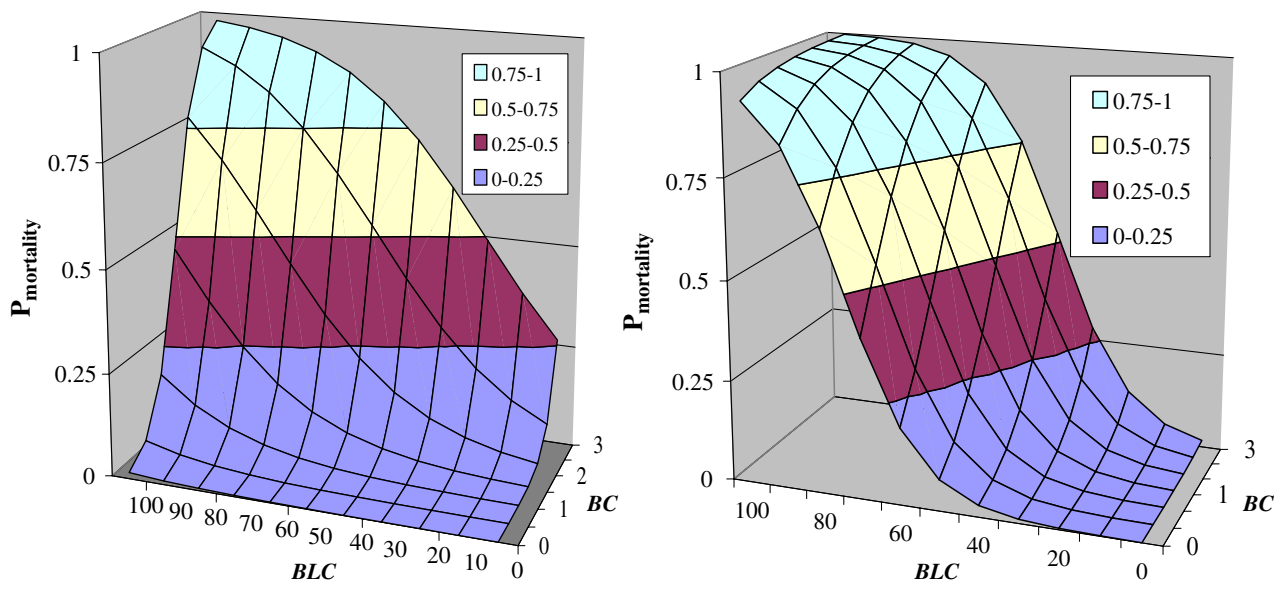

\section{Results}

In all, 331 laricio and 330 maritime pines were sampled, covering a broad range of tree dimensions and thermal damage. Overall, laricio pine showed a higher mortality rate than maritime pine; about $40 \%$ of laricio pines died compared to $30 \%$ of maritime pines (Table 2).

\subsection{Species-specific mortality models}

The three best models for each pine species are presented in Table 3. Marl and Larl used three explanatory variables (BF, BC, and BLC). Mar2 and Lar2 used two explanatory variables (BF and BLC), as did Mar3 and Lar3 (BF and BC). Significance values were all very high (likelihood ratio test $P \leq 0.0001$ ) with concordance indices of more than 0.85 . Model fits were better for laricio than for maritime pine, especially with BLC (Lar1, Lar2, Mar1, and Mar2). BC was indecisive for laricio pine (Lar2 was almost as good as Larl), but was significant for maritime pine since the performance of Mar2 was poorer than that of Marl. As expected, the resampling used to avoid the sparseness effect decreased joint significance (Table 4), which was initially biased. But significance remained satisfactory, and the models were well fitted (e.g., Lar1 model in Fig. 2).

Figure 3, derived from models Larl and Marl, shows mortality probabilities for the two pines at median diameters $(\mathrm{DBH}=35 \mathrm{~cm})$. Maritime mortality was sensitive to $\mathrm{BC}$ decreasing with this index. Laricio pine was less sensitive to $\mathrm{BC}$. As a result, mortality at low $\mathrm{BC}$ was far higher in laricio than in maritime pines. Small laricio pines $(\mathrm{DBH}=25 \mathrm{~cm})$ were more vulnerable to fire than maritime pines. In contrast, large and medium laricio pines were less vulnerable than maritime pines (Fig. 4).

\subsection{Model common to both species}

A model that included both species selected using the Akaïke criterion (Table 5), MarLarl, showed significant differences between the two species, mostly explained by $\mathrm{BC}$. The $\mathrm{BF} \times$ Species interaction was not significant, consistent with the hypothesis that BF is a speciesindependent indicator of bark insulating properties. The
Fig. 4 Mortality probability in relation to diameter at breast height $(D B H)$, in maritime (left) and laricio (right) pines (Marl and Lar1 models)
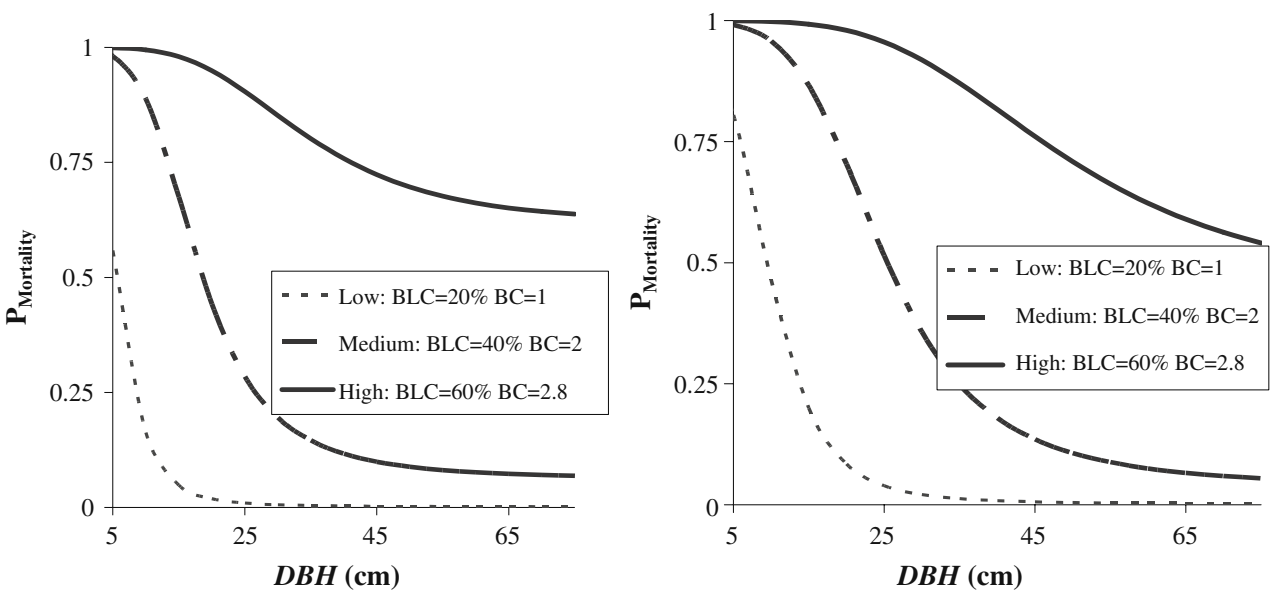
Table 5 Logistic models common to both species (MarLar1)

\begin{tabular}{|c|c|c|c|c|c|c|c|c|}
\hline Intercept & $\mathrm{BF}$ & $\mathrm{BLC}_{\mathrm{mod}}$ & $\mathrm{BC}$ & $\begin{array}{l}\mathrm{BLC}_{\text {mod }} \times \\
\text { Species }\end{array}$ & $\begin{array}{l}\mathrm{BC} \times \\
\text { Species }\end{array}$ & Deviance & DF & $\mathrm{CI}$ \\
\hline $\begin{array}{c}-0.225 \pm \\
0.54\end{array}$ & $\begin{array}{l}-9.71 \pm \\
0.92 * * *\end{array}$ & $\begin{array}{l}0.0498 \pm \\
0.0087^{* * *}\end{array}$ & $\begin{array}{l}2.62 \pm \\
0.372 * * *\end{array}$ & $\begin{array}{c}0.0352 \pm \\
0.0141^{*}\end{array}$ & $\begin{array}{r}-1.26 \pm \\
0.35^{* * *}\end{array}$ & $\begin{array}{l}415 \text { (Null 857) AIC } \\
427\end{array}$ & $\begin{array}{l}655 \text { (Null } \\
660)\end{array}$ & 0.930 \\
\hline
\end{tabular}

$B F$ bark factor, $B L C_{m o d}$ bole length charred (modified), $B C$ bark char, $D$ deviance, $A I C$ Akaike criterion, $D F$ degrees of freedom, $C I$ concordance index

$* * * P<0.001 ; * * P<0.001 ; * P<0.1\left(\chi^{2}\right.$ test $)$

species index was significant (through variables $\mathrm{BLC}_{\bmod } \times$ Species and $\mathrm{BC} \times$ Species), showing different behavior between the pines in terms of postfire mortality. For a given bark factor, similar damage to the crown (BLC) caused higher mortality in laricio than maritime pine. Similar damage to bark (BC) caused lower mortality in laricio than maritime pine. Using $\mathrm{BLC}_{\text {mod }}$ instead of $\mathrm{BLC}$ did not significantly alter the results, but was more satisfactory for species comparisons. A significant correlation was found in the dataset between $\mathrm{BC}$ and $\mathrm{BLC}_{\bmod }\left(r^{2}=0.576\right)$, due to probable correlations between residence time (associated with $\mathrm{BC}$ ) and flame height (associated with $\mathrm{BLC}_{\mathrm{mod}}$ ). For the sake of simplicity, this correlation between measured variables was used to establish a single independent fire damage variable FD (\%):

For a given FD,

$-B C=1.35+0.013 \times F D$

Laricio mortality was higher under almost all fire conditions, frequently up to $30 \%$ and even $100 \%$ for young pines experiencing intense fire. Differences between the species were less significant in old pine stands experiencing minor fire damage (Fig. 5). The vulnerability of young laricio may be explained by their smaller size and poorer self-pruning capacities, resulting in more low branches than in maritime pine.

\section{Discussion and conclusion}

\subsection{Model evaluation}

As expected, short-term tree mortality decreased with BF and increased with BLC and BC. Model fits were very good even without using crown scorch volume as a predictive variable given that this probably correlates with bole length charred (bole length charred itself has no physical meaning in terms of indicating damage). Taking into account a possible sparseness effect (artificial decrease in deviance) by resampling had little effect on the results. The fact that only short-term mortality was modeled may also go some way to explaining the very good fit obtained with the models as short-term mortality is directly related to the fire's physical characteristics (Hely et al. 2003; Sidoroff et al. 2007). Delayed mortality, often due to indirect factors such as bark beetles or local drought conditions, is known to introduce more variability into model predictions (Ryan and Amman 1994) and should be taken into account in management applications.

The relative insensitivity of laricio mortality to $\mathrm{BC}$ at low and high BLC is surprising (Fig. 3, laricio pine). This could mean that its cambium is well protected under the bark even when severe damage is sustained, but the relatively thin bark of the laricio pine does not support this hypothesis. Another opposing hypothesis is that laricio pine is already very sensitive to the lowest levels of bark damage $(\mathrm{BC}=1)$, meaning that the $\mathrm{BC}$ scale is not a good linear
Fig. 5 Absolute and relative differences in mortality probabilities between maritime (left) and laricio (right) pine in relation to age and fire damage $F D$ (\%; MarLar1 model)
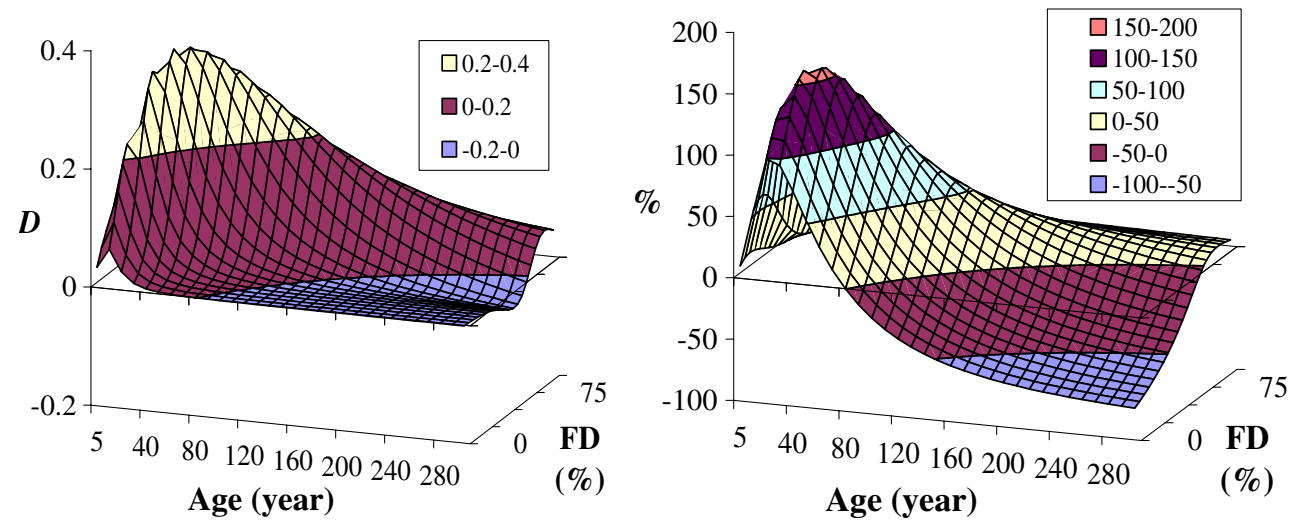
predictor of mortality in a logistic regression. But the model's very good fit does not support this second hypothesis. An explanation may be found in BC/BLC correlations. In the dataset, cases with low $\mathrm{BC}$ and high BLC (and vice versa) were rare because severities near the ground and in the canopy were correlated; consequently, the model is probably less accurate in these cases. This does not raise a serious problem for operational use because the model will be used within the parameter range that provides a very good fit. But this slightly weakens interpretations in terms of species resistance to fire damage.

\subsection{Comparison between resistance in the two species}

At all given ages, the probability of laricio mortality was far higher than that of maritime pine at the same level of bole damage. It was higher for almost all ages and fire damage percentages (Fig. 5), especially for young trees. These differences may for the most part be explained by diameter and height growths, which were significantly lower in laricio pine, but also by the fact that laricio bark was thinner for a same DBH and it had more low branches. In addition, maritime pine bark is more fissured and laminated than in laricio, which favors desquamation when burning (Fernandes and Rigolot 2007) and limits heat flux on the maritime pine bole.

The interspecies differences in short-term mortality suggest that more frequent fires place laricio pine at a disadvantage with respect to maritime pine. The postfire regeneration of laricio pine is unknown, but other $P$. nigra generally lack regeneration, especially when compared to maritime pine (Pausas et al. 2008). These results are consistent with Carcaillet et al. (1997), who explain that the extension of maritime pine and the decrease in laricio pine were caused by an increase in fire frequency during the Holocene.

\subsection{Management guidelines}

Although the Lar1 and Mar 1 models can only predict shortterm mortality, they can nevertheless be used by forest managers looking to assess individual tree mortality in the year following a fire.

First, as the disadvantage of the laricio pine is more marked in its young stages, forest managers should concentrate their efforts in pure laricio or mixed stands less than 60-80 years old, even if the value of old growths is higher. Second, given that laricio pine is more vulnerable to bark damage and flame height, residence time and fire intensity must be reduced, especially near the ground, by removing surface fuel. Litter and understorey can be controlled by mechanical clearing or prescribed burning in sufficiently old stands. Ladder fuel can be diminished by pruning, and this can reduce crowning and protect the seedlers required for regeneration. The selective thinning of maritime pine can also reduce competition with laricio. Moderate thinning is recommended even in pure laricio stands to enhance radial growth which increases tree resistance (through thicker bark), but also to reduce crown fire risk. Dreyfus (1990) recommends moderate thinning of $P$. nigra stands combined with brush clearing in 30-40year-old stands where growth is maximal. When postfire logging is absolutely necessary for safety or esthetic reasons, we recommend cutting the fewest pines possible because even seriously injured trees with low survival probabilities can provide a suitable habitat for the endemic Corsican nuthatch (Moneglia et al. 2009).

The recent increase in fire occurrence and severity coupled with the maritime pine's better adaptation to dry conditions and its postfire resistance suggest that the laricio pine's situation in Corsica could deteriorate rapidly. The inclusion of postfire regeneration capacities and survival abilities in population dynamics models (Franc et al. 2000) would allow the future of Corsican forests to be predicted under different fire regimes and management scenarios, enhancing the conservation of this important ecosystem in the long term.

Acknowledgments We are grateful to Jean-Claude Thibault (Parc Naturel Régional de Corse) for his assistance during the fieldwork, to Denis Soulé (ONF Corte) and Bernard Recorbet (DIREN Corse) for their help in finding funding, to Nabila Hamza for providing FNI data, and to Paulo Fernandes and Jean-Noel Candau for reviewing an earlier version of the manuscript.

\section{References}

Afzal-Rafii Z, Dodd R (2007) Chloroplast DNA supports a hypothesis of glacial refugia over postglacial recolonization in disjunct populations of black pine (Pinus nigra) in western Europe. Mol Ecol 16(4):723-736

Carcaillet C, Barakat HN, Panajotis C, Loisel R (1997) Fire and lateHolocene expansion of Quercus ilex and Pinus pinaster on Corsica. J Veg Sci 8(1):85-94

Dreyfus P (1990) Produire pour protéger ou comment limiter le risque d'incendie dans les peuplements de pin noir d'Autriche des Alpes sèches. Rev For Fr 42:207-217

Fernandes PM, Rigolot R (2007) The fire ecology and management of maritime pine (Pinus pinaster Ait.). For Ecol Manag 241:1-13

Fernandes PM, Vega JA, Jimenez E, Rigolot R (2008) Fire resistance of European pines. For Ecol Manag 256:246-255

Franc A, Gourlet-Fleury S, Picard N (2000) Une introduction à la modélisation des forêts hétérogènes. Ecole Nationale du Génie Rural, des Eaux et des Forêts. Nancy, France. 312 p

Hely C, Flannigan M, Bergeron Y (2003) Modelling tree mortality following wildfire in the southeastern Canadian mixed-wood boreal forest. For Sci 49(4):566-576

Ihaka R, Gentleman R (1996) A language for data analysis and graphics. J Comput Graph Stat 5(3):299-314

Jenkins MJ (1990) The relationship between fire and bark beetle attack in Western North American forests. In: Viegas DX (ed) Proceedings of the First International Conference on Forest Fire Research, Coimbra, Portugal C.1, $12 \mathrm{p}$ 
McCullagh P, Nelder JA (1989) Generalized linear models. Ed Chapman and Hall (2nd edition)

McHugh CW, Kolb TE (2003) Ponderosa pine mortality following fire in northern Arizona. Int J Wildland Fire 12(1):7-22

Moneglia P, Besnard A, Thibault J-C, Prodon R (2009) Habitat selection of the Corsican nuthatch (Sitta whiteheadi) after a fire. J Ornithol 150(3):577-583

Ordonez JL, Retana J, Espelta JM (2005) Effects of tree size, crown damage, and tree location on post-fire survival and cone production of Pinus nigra trees. For Ecol Manag 206:109-117

Pausas JG, Lovet J, Rodrigo A, Vallejo R (2008) Are wildfires a disaster in the Mediterranean basin? - a review. Int J Wildland Fire 17:713-723

Prodon R, Thibault J-C (2002a) L'avifaune reproductrice des futaies de pin laricio en Corse. Rev For Fr 2:131-141

Prodon R, Thibault J-C (2002b) Le pin laricio est-il une espèce clé pour la Sitelle Corse? Rev Ecol 57:329-341

Regelbrugge JC, Conard SG (1993) Modeling tree mortality following wildfire in Pinus ponderosa forests in the Central Sierra Nevada of California. Int J Wildland Fire 3:139-148

Rego FC, Rigolot E (1990) Heat transfer through bark. A simple predictive model. In: Goldammer JG, Jenkins MJ (eds) Fire in ecosystem dynamics: proceedings of the Third International Symposium on Fire Ecology. FRG, Freiburg, pp 157-160

Rigolot E (1992) Diagnostique précoce de la survie du pin d'Alep et du pin pignon après incendie. Rev. Anal. Spatiale Quantitative et Appliquée: vol 32

Rigolot E (2004) Predicting postfire mortality of Pinus halepensis Mill. and Pinus pinea. L Plant Ecol 171:139-151
Ryan KC (1982) Evaluating potential tree mortality from prescribed burning. In: Baumgartner DM (ed), p 167-179

Ryan KC, Amman GD (1994) Interactions between fire-injured trees and insects in the greater Yellowstone area. Plants and their Environments. In: US Department of Interior and National Park Service (Ed), Book of Proceedings of the First Biennial Scientific Conference on the Greater Yellowstone Ecosystem 1991. WY p 259

Ryan KC, Reinhardt ED (1988) Predicting postfire mortality of seven western conifers. Can J For Res 18:1291-1297

Ryan KC, Rigolot R, Botelho H (1994) Comparative analysis of fire resistance and survival of mediterranean and western north american conifers. In: Society of American Foresters (Ed) Book of Proceedings of the 12th Conference on Fire and Forest Meteorology, $\mathrm{p} 701$

Sidoroff K, Kuuluvainen T, Tanskanen H, Vanha-Majamaa I (2007) Tree mortality after low-intensity prescribed fires in managed Pinus sylvestris stands in southern Finland. Scand J For Res 22:2-12

Sullivan BT, Fettig CJ, Otrosina WJ, Dalusky MJ, Berisford CW (2003) Association between severity of prescribed burns and subsequent activity of conifer-infesting beetles in stands of longleaf pine. For Ecol Manag 185:327-340

Van Mantgem P, Schwartz M (2003) Bark resistance of small trees in Californian mixed conifer forests: testing some model assumptions. For Ecol Manag 178:341-352

Zaghi D (2008) Management of Natura 2000 habitats: 9530 (Sub)Mediterranean pine forests with endemic black pines. European Commission, Technical Report 